\title{
Н.А. Томилов
}

\section{ТОМСК В МОЕЙ СУДЬБЕ ИСТОРИКА}

\begin{abstract}
Статья содержит сведения о VII международном научном семинаре «Интеграция археологических и этнографических исследований», который омские научные учреждения проводили 9-10 июня 1999 г. в Москве в рамках III конгресса этнографов и антропологов России, о сделанном на семинаре докладе А.Н. Жеравиной о жизни и деятельности томского историка и археолога З.Я. Бояршиновой. Характеризуется роль томской исторической школы в формировании научных центров в области исторических знаний в других городах Сибири, в том числе в Омске, где сложились этнографическая, этноархеологическая, культурологическая и музееведческая научные школы.

Ключевые слова: история; этнография; ученый; научная школа; университет.
\end{abstract}

9-10 июня 1999 г. в Зеленом зале главного корпуса Российской академии наук проходила работа VII международного научного семинара «Интеграция археологических и этнографических исследований». Этот семинар был включен в программу III конгресса этнографов и антропологов России, открытие которого состоялось в Москве в Большом концертном зале «Наука» Российской академии наук. Из семи докладов, заслушанных на пленарном заседании конгресса, один был представлен по тематике VII семинара - это мой доклад «Этноархеология и проблемы этнографо-археологических комплексов в отечественной науке».

Сам названный выше ежегодный международный научный семинар был посвящен двум памятным датам - 80-летию со дня рождения выдающегося московского историка и этнографа Ильи Самуиловича Гурвича и 90 -летию со дня рождения выдающегося томского историка и археолога Зои Яковлевны Бояршиновой [1. С. 134-138; 2. С. 3-21]. И вот доклад о жизни и деятельности 3.Я. Бояршиновой мы попросили сделать на семинаре Анису Нурлгаяновну Жеравину, которую мы в Томске все звали Анной Георгиевной. Уже тогда она была известным историком, имела степень доктора исторических наук и звание профессора, работала на историческом факультете Томского государственного университета (ТГУ), в научном плане имела достижения в исследовании истории кабинетского хозяйства Сибири и положения приписных крестьян в этом регионе, а также успехи в формировании группы ученых по изучению истории старообрядчества Сибири. Текст ее доклада был опубликован в сборнике материалов семинара [3. С. 20-22].

В тот период в Томске шла подготовка сборника научных трудов «Человек в истории», посвященного памяти профессора, доктора исторических наук 3.Я. Бояршиновой. А.Н. Жеравина пригласила меня участвовать в этом сборнике, и между нами завязалась переписка. Конечно, мы были знакомы друг с другом и раньше, когда в начале 1960-х гг. я со своими сокурсниками учился на историко-филологическом факультете ТГУ, а Анна Георгиевна была аспиранткой на этом же факультете, а после осваивала азы ассистентской работы. Но это, как говорится, было формальное знакомство, а вот с подготовкой сборника и проведением омичами в Москве Международного научного семинаpa, посвященного 90-летию 3.Я. Бояршиновой, между нами установились дружеские отношения, которые продолжаются и поныне.

Возвращаясь к работе VII международного семинара по этноархеологии, отмечу, что в нем приняли участие 75 ученых из 17 городов России, а также из Казахстана, Кыргызстана и Украины, а материалы в сборник семинара прислали также ученые из Венгрии, Испании и Китая. Кроме А.Н. Жеравиной с докладом в связи с юбилейной датой 3.Я. Бояршиновой выступила и томская исследовательница Л.М. Плетнева. Ее доклад назывался «Метод комплексного изучения древней истории Западной Сибири в связи с исследованиями 3.Я. Бояршиновой» [4. С. 6].

Четыре дня встреч во время работы Конгресса этнографов и антропологов России и нашего семинара способствовали более тесному общению ученых-историков, археологов, этнографов, культурологов и музееведов. В семинаре по этноархеологии участвовали тогда многие известные в стране и за рубежом ученые, и среди них А.А. Азизян и С.Е. Ажигали из Алма-Аты, М.Ф. Косарев, Г.Е. Марков и Ш.Ф. Мухамедьяров из Москвы, А.М. Решетов из Санкт-Петербурга, Ф.Т. Валеев из Казани, А.В. Головнев из Екатеринбурга, В.И. Семенова из Тюмени, Л.М. Плетнева, М.П. Черная и Л.А. Чиндина из Томска, А.В. Харинский из Иркутска, О.В. Дьякова и В.А. Тураев из Владивостока и другие. Ну и, конечно же, большая группа омских ученых, и все мы тогда с большим уважением и теплотой общались с А.Н. Жеравиной и другими учеными из Томска.

Тогда в сборник «Человек в истории» я сдал небольшую статью под названием «В память о Зое Яковлевне Бояршиновой - крупном сибиреведе и гуманисте» [5. С. 37-38]. В этой работе была дана краткая оценка научного наследия и научно-организа-ционного вклада 3.Я. Бояршиновой в системы сибирского высшего образования и сибирской науки. Тем ученым, кто 
ратует за комплексный подход к изучению проблем истории Сибири, особенно близок и дорог ее вклад в интеграцию археологии, этнографии и истории Сибири. Поэтому-то ученые России, объединяющиеся вокруг ежегодного научного семинара, организуемого омскими научными учреждениями совместно с ведущими научными центрами страны, и решили VII международный научный семинар «Интеграция археологических и этнографических исследований» посвятить 90-летию со дня рождения 3.Я. Бояршиновой. Надо отметить, что второе юбилейное событие - 80-летие И.С. Гурвича - нашло отражение в докладах Е.П. Батьяновой и Т.В. Лукьянченко (Москва) «Илья Самуилович Гурвич (страницы творческой биографии)» и в моем совместном с В.С. Томиловой докладе о вкладе И.С. Гурвича в изучение этнической истории народов СССР. А.Н. Жеравина обратила тогда наше внимание на то, что 3.Я. Бояршинова и И.С. Гурвич хорошо знали и ценили друг друга.

3.Я. Бояршинова сыграла в моей судьбе как историка значительную роль, хотя первым моим учителем в области этнографии была томская исследовательница Галина Ивановна Пелих, которая преподала мне серьезную практику этнографических экспедиционных работ по сбору полевых материалов. Но и 3.Я. Бояршинова проявляла ко мне внимание в студенческие годы. В 1963-1964 гг. мне повезло работать под руководством 3.Я. Бояршиновой в качестве старшего лаборанта кафедры археологии, этнографии и истории Сибири ТГУ, которую она организовала и возглавила. Тогда мне пришлось находиться с ней в одном кабинете и присутствовать при многих ее разговорах с учеными из разных городов, многочасовых консультациях ею студентов и аспирантов. Да и сам я нередко и в тот период, и позже, вплоть до отъезда из Томска в Омск в 1974 г. на работу в Омский государственный универси- тет, нередко обращался к 3.Я. Бояршиновой с просьбами помочь в решении того или иного научного вопроса. И поэтому где-то, по большому счету, я тоже считаю себя ее учеником.

Томский государственный университет как крупный научный центр в области исторического знания играл и играет существенную роль в подготовке высококвалифицированных историков в Сибири. Сама юбиляр А.Н. Жеравина является ярким примером этого процесса. Помню, когда я переезжал на работу в Омск, мой друг, тогда заведующий Проблемной научноисследовательской лабораторией истории, археологии и этнографии Сибири ТГУ, Анатолий Тихонович Топчий пытался убедить ректора профессора Александра Петровича Бычкова задержать меня в Томске, то тот ответил ему, что Омск - это кузница кадров, и пусть Николай Аркадьевич едет на работу в новый университет. Кстати, А.П. Бычков в свое время существенно помог мне восстановиться после службы в армии на учебу в ТГУ и получить диплом историка. Он же в 1968 г. дал согласие на ходатайство первого заведующего вышеназванной научной лаборатории доцента, а позднее профессора, доктора исторических наук Александра Павловича Бородавкина на прием меня на работу в лабораторию младшим научным сотрудником.

В целом я благодарен всем замечательным преподавателям ТГУ, которые дали нам фундаментальные знания в области исторических наук. Но особенно я благодарен за существенную поддержку моего пути в науку и в жизнь 3.Я. Бояршиновой, А.П. Бородавкину, профессору С.С. Григорцевичу, который в трудные для меня с женой Валентиной Сергеевной дни говорил ей: «Не переживайте, Ваш Николай Аркадьевич обязательно будет профессором», - доценту (в будущем профессору, доктору исторических наук) В.И. Матющенко, профессору, доктору исторических наук М.Е. Плотниковой.

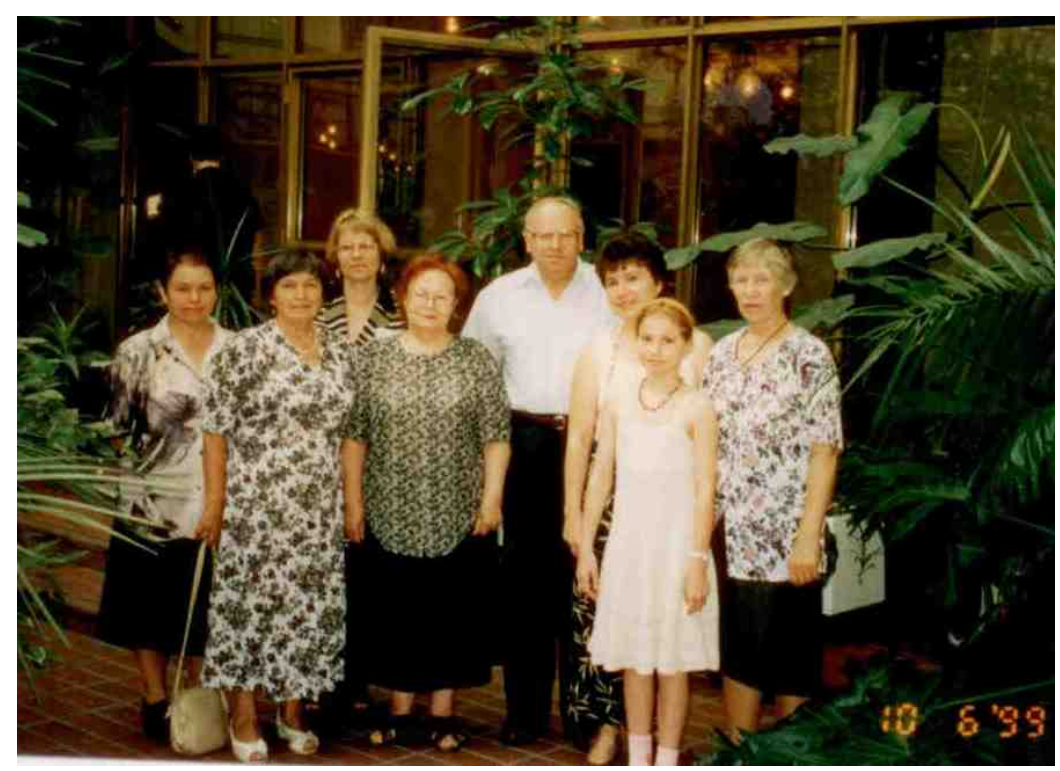

На снимке омские и томские ученые - участники VII международного научного семинара

«Интеграция археологических и этнографических исследований»: (слева направо) А.И. Боброва, Л.А. Чиндина,

С.Н. Корусенко, А.Н. Жеравина, Н.А. Томилов, М.П. Черная, Л.А. Плетнева, (крайняя справа). Г. Москва. 10 июня 1999 г. 
В Томске сформировался круг моих друзей и соратников, из которых многие стали известными учеными, это, прежде всего, В.А. Дремов, Н.П. Кириллов, В.М. Кулемзин, Э.Л. Львова, Н.В. Лукина, Л.М. Плетнева, Ю.С. Плотников, А.Т. Топчий, Л.А. Чиндина. Мои связи с Томском после переезда на работу в Омск никогда не прерывались. Я относительно регулярно принимал участие во всероссийских научных конференциях по археологии и этнографии Западной Сибири, которые проходят в ТГУ один раз в три года. Выступал с докладами и на других конференциях в Томске. Томские коллеги и друзья постоянно участвуют в наших омских конференциях. Несколько лет мне пришлось быть членом Научного совета по интеграции академической науки и вузовского образования, сформированного на базе ТГУ и возглавляемого его ректором профессором Г.В. Майером, а со стороны Сибирского отделения РАН - академиком В.И. Молодиным. Все это привело к тому, что меня, как и в свое время А.Н. Жеравину, наградили медалью «За заслуги перед Томским государственным университетом». И несмотря на то, что в разные годы меня наградили орденом Дружбы, орденом Почета, присудили звание «Заслуженный работник высшего профессионального образования Российской Федерации», приняли в действительные члены Академии гуманитарных наук (Россия), Российской академии естественных наук и Российской академии социальных наук, наградили медалью Л.Н. Гумилева Евразийского национального университета (г. Астана) и многими другими почетными званиями и наградами, все же эту медаль от ТГУ я ценю очень высоко.

Моя творческая деятельность и творческие дерзания многих моих друзей и коллег начинались и развивались в Томском государственном университете, который остается для меня колыбелью многих моих научных поисков, приведших к созданию уже в Омске научных школ в области этнографии, этноархеологии, культурологии и музееведения [6. С. 80- 86; 7. С. 3444; 8. C. 185-203; 9.; 10. C. 27-33; 11. С. 285-295]. И наша благодарность за это Томскому государственному университету и в первую очередь его замечательным ученым-историкам.

\section{ЛИТЕРАТУРА}

1. Корусенко С.Н. Омский семинар в Москве // Культурологические исследования в Сибири. Омск, 1999. Вып. 2. С. 134-138.

2. Томилов Н.А. Российский международный научный семинар «Интеграция археологических и этнографических исследований» (к 10 -летию со дня основания) // Интеграция археологических и этнографических исследований. Омск ; Ханты-Мансийск : Изд-во Омск. гос. пед. унта, 2002. C. 3-21.

3. Жеравина А.Н. Краткий очерк жизни и деятельности З.Я. Бояршиновой // Интеграция археологических и этнографических исследований : сб. науч. тр. М. ; Омск : Изд-во Омск. гос. пед. ун-та, 1999. С. 20-22.

4. VII Международный научный семинар «Интеграция археологических и этнографических исследований», посвященный 80-летию со дня рождения И.С. Гурвича и 90-летию со дня рождения 3.Я. Бояршиновой. Москва, 8-11 июня 1999 г. / отв. ред. Н.А. Томилов. Москва ; Омск : Изд. Омск. гос. ун-та, 2000. 26 с.

5. Томилов Н.А. В память о Зое Яковлевне Бояршиновой - крупном сибиреведе и гуманисте // Человек в истории. Памяти профессора 3.Я. Бояршиновой. Томск : Изд-во Том. ун-та, 1999. С. 37-38.

6. Dudoignon S.A. Islam in Siberia: Historical and Anthropological Aspects // Asiatic Russia Partnerships and Communities in Eurasia. Kolkata, 2009. P. 80-86.

7. Жигунова М.А. Омская этнографическая научная школа // Культурологические исследования в Сибири. 2014. № 1. С. 34-44.

8. Жигунова М.А., Томилов Н.А. Научные и научно-педагогические школы // Университет в истории и история университета : к 40-летию Омского государственного университета имени Ф.М. Достоевского : очерки. Омск : Изд. дом «Наука», 2014. С. $185-203$.

9. Захарова И.В., Томилов Н.А. Этнографические научные центры Западной Сибири середины XIX - начала XXI века. Омский этнографический центр / отв. ред. В.П. Корзун, В.И. Матющенко. Омск : Изд. дом «Наука», 2007. 400 с.

10. Томилов Н.А. Омский музееведческий научный центр // Культурологические исследования в Сибири. 2014. № 1. С. $27-33$.

11. Томилов Н., Жигунова М. Омский научный этнографический центр: штрихи к портрету // Антропология академической жизни: Междисциплинарные исследования. М., 2010. Т. ІІ. С. 285-95.

Tomilov Nikolay A. Omsk branch of Institute of archeology and ethnography of the Siberian office of Russian Academy of Science, F.M. Dostoyevsky Omsk State University (Omsk, Russia). E-mail: n.a.tomilov@gmail.com

\section{TOMSK IN MY FORTUNE OF HISTORIAN.}

Key words: history; ethnography; scientist; school of sciences; university.

The article contains data on the VII international scientific seminar "Integration of archaeological and ethnographic research" which Omsk scientific institutions carried out on June 9-10, 1999 in Moscow as a part of the III congress of ethnographers and anthropologists of Russia, as well as on A.N. Zheravina's report at that seminar about the life and activity of Tomsk historian and archeologist Z.Ya. Boyarshinova. The role of the Tomsk historical school in formation of scientific centers in the field of historical knowledge in other cities of Siberia is characterized, including Omsk where there are ethnographic, ethnoarchaeological, culturological and museological scientific schools. The author through a prism of personal experience analyzes value of Tomsk State University as center of formation of historical specialists, touches upon a subject of a role of teachers, colleagues in formation and development of the personality of the scientist. The author focuses attention on importance of the scientific communication giving powerful impulses to creative research, opening the new horizons of professional and personal growth. The thought of need of geography expansion of scientific contacts, exchange of the new ideas and scientific achievements is emphasized. Fruitful experience of realization scientific seminars, conferences, the congresses uniting scientists of different regions and the countries is given as a good example. The author shows dynamics of development of a scientific and educational complex of Siberia, relying on the experience as the member of Scientific Council on integration of the academic science and high school education which has been created on the basis of the Tomsk State University. The retrospective view of sources of the professional growth and development allows the author to write with all objectivity that the success- 
ful solution of the tasks facing science and education nowadays is impossible without support on experience of the senior generations of university professors and all teachers which could carry their pupils with the self-sacrifice, profound knowledge and devotion to the profession. This communication of university generations allows keeping and increasing greatly values of profession which in that case becomes fortune.

\section{REFERENCES}

1. Korusenko, S.N. (1999) Omskiy seminar v Moskve [Omsk seminar in Moscow]. Kul'turologicheskie issledovaniya v Sibiri. 2. pp. 134-138.

2. Tomilov, N.A. (2002) Rossiyskiy mezhdunarodnyy nauchnyy seminar "Integratsiya arkheologicheskikh i etnograficheskikh issledovaniy" [Russian International Seminar "Integration of Archaeological and Ethnographic Studies"]. In: Tomilov, N.A. (ed.) Integratsiya arkheologicheskikh $i$ etnograficheskikh issledovaniy [Integration of Archaeological and Ethnographic Research]. Omsk; Khanty-Mansiysk: Omsk State Pedagogical University. pp. 3-21.

3. Zheravina, A.N. (1999) Kratkiy ocherk zhizni i deyatel'nosti Z.Ya. Boyarshinovoy [A short essay on the life and work of Z.Ya. Boyarshinova]. In: Tomilov, N.A. (ed.) Integratsiya arkheologicheskikh i etnograficheskikh issledovaniy [Integration of Archaeological and Ethnographic Research]. Omsk; Khanty-Mansiysk: Omsk State Pedagogical University. pp. 20-22.

4. Tomilov, N.A. (ed.) (1999) VII Mezhdunarodnyy nauchnyy seminar "Integratsiya arkheologicheskikh i etnograficheskikh issledovaniy", posvyashchennyy 80-letiyu so dnya rozhdeniya I.S. Gurvicha i 90-letiyu so dnya rozhdeniya Z.Ya. Boyarshinovoy [The Seventh International Seminar "Integration of Archaeological and Ethnographic Research" dedicated to the 80th anniversary of the birth of I.S. Gurvich and the 90th anniversary of Z.Ya. Boyarshinova]. Moscow; Omsk: Omsk State University.

5. Tomilov, N.A. (1999) V pamyat' o Zoe Yakovlevne Boyarshinovoy - krupnom sibirevede i gumaniste [In memory of Zoya Yakovlevna Boyarshinova - a major Siberian researcher and humanist]. In: Zheravina, A.N. (ed.) Chelovek v istorii. Pamyati professora Z. Ya. Boyarshinovoy [Person in History. In Memory of Professor Z.Ya. Boyarshinova]. TomskTomsk State University. pp. 37-38.

6. Dudoignon, S.A. (2009) Islam in Siberia: Historical and Anthropological Aspects. In: Chatterjee, S., Sengupta, A. \& Bhattacharya, S. (eds) Asiatic Russia Partnerships and Communities in Eurasia. Kolkata: Maulana Abul Kalam Azad Institute of Asian Studies. pp. 80-86.

7. Zhigunova, M.A. (2014) Omskaya etnograficheskaya nauchnaya shkola [Omsk Ethnographic School]. Kul'turologicheskie issledovaniya v Sibiri. 1. pp. 34-44.

8. Zhigunova, M.A. \& Tomilov, N.A. (2014) Nauchnye i nauchno-pedagogicheskie shkoly [Scientific and pedagogical schools]. In: Tomilov, N.A. (ed.) Universitet $v$ istorii $i$ istoriya universiteta: $k$ 40-letiyu Omskogo gosudarstvennogo universiteta imeni F.M. Dostoevskogo: ocherki [University in history and university history: To the 40th anniversary of the Omsk State University named after F.M. Dostoevsky. Essays]. Omsk: Nauka. pp. 185203.

9. Zakharova, I.V. \& Tomilov, N.A. (2007) Etnograficheskie nauchnye tsentry Zapadnoy Sibiri serediny XIX - nachala XXI veka. Omskiy etnograficheskiy tsentr [Ethnographic centres of Western Siberia in the mid-19th - early 21st centuries. The Omsk Ethnographic Center]. Omsk: Nauka.

10. Tomilov, N.A. (2014) Omskiy muzeevedcheskiy nauchnyy tsentr [The Omsk Museum Studies Center]. Kul'turologicheskie issledovaniya v Sibiri. 1. pp. 27-33.

11. Tomilov, N. \& Zhigunova, M. (2010) Omskiy nauchnyy etnograficheskiy tsentr: shtrikhi k portretu [The Omsk Ethnographic Centre: Strokes to the portrait]. In: Komarova, G.A. (ed.) Antropologiya akademicheskoy zhizni: Mezhdistsiplinarnye issledovaniya [Anthropology of Academic Life: Interdisciplinary Research]. Vol. 2. Moscow: RAS. pp. 285-95. 